\title{
Estimating amount and timing of Late Palaeozoic uplift and erosion in the Rønne Graben, Bornholm, Denmark
}

\author{
SOLVEJG KOLBYE JENSEN \& SØREN BOM NIELSEN
}

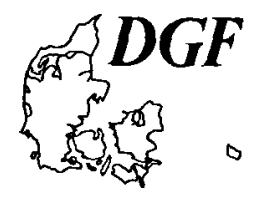

\author{
Jensen, S. K. \& Nielsen, S. B.: Estimating amount and timing of Late Palaeozoic uplift \\ and erosion in the Rønne Graben, Bornholm, Denmark. Bulletin of the Geological \\ Society of Denmark, Vol. 42, pp. 23-33. Copenhagen, 1995-10-31. \\ https://doi.org/10.37570/bgsd-1995-42-03
}

\begin{abstract}
Late Palaeozoic uplift and erosion is evidenced by a discontinuous vitrinite reflectance profile of the Pernille-1 well situated in the Rønne Graben. Modelling vitrinite reflectance evolution by the methods of basin modelling, the unconformity is estimated to represent Late Carboniferous uplift and erosion of 3,300 m of Upper Silurian and Devonian sediments. Given a vitrinite reflectance value of $1.7 \%$ at the erosional surface, the maximum tempera-ture obtained during deepest burial is $160-165^{\circ} \mathrm{C}$, corresponding to a geothermal gradient of approximately $50^{\circ} \mathrm{C} / \mathrm{km}$. The sensitivity of the erosion estimate to the choice of model parameter values is quantified. For example, a $\pm 10 \%$ uncertainty in the geothermal gradi-ent equals an uncertainty of $\pm 400 \mathrm{~m}$ in the erosion estimate.
\end{abstract}

Solvejg Kolbye Jensen \& Søren Bom Nielsen, Department of Earth Science, Aarhus University, DK-8000 Århus C, Denmark. January 23rd, 1995.

\section{Introduction}

The Rønne Graben off Bornholm (Fig. 1) is suggested to be a Carboniferous/Permian pull-apart basin developed in a releasing bend during dextral strike-slip movements along the Tornquist Zone (Vejbæk 1985; Liboriussen et al. 1987; Hamann 1994).

In the Rønne Graben, Lower Palaeozoic sediments deposited on a stable platform are succeeded by thick Silurian strata deposited during rapid subsidence in a foreland type basin to the German/Polish Caledonides. Carboniferous uplift and subsequent erosion were followed by accumulation of Permian and Mesozoic sediments in the graben, reflecting subsidence in connection with the initiation and development of the Tomquist Zone. Late Cretaceous/Early Tertiary transpressional movements resulted in inversion and reactivation of existing faults throughout the graben (Hamann 1994).

Evidence of a major Pre-Permian unconformity representing the Late Palaeozoic uplift and subsequent erosion is present as a truncation of seismic reflections throughout the Rønne Graben and in the discontinuous (segmented) trend of vitrinite reflectance $\left(R_{0}\right)$ and spore colour profiles of the Pernille-1 well (Robertson Group 1989).

The fact that discontinuous (segmented and curvilinear) vitrinite reflectance profiles can be indicative of changes in the geological environment during deposition, such as changes in sedimentation rates, changes in geothermal gradients, or the presence of an unconformity, has been noted by many authors (e.g. Middleton 1982; Katz et al. 1988). The irreversible nature of vitrinite reflectance evolution with increasing temperature implies that a segmented profile is indicative of a period of uplift and erosion. By applying quantitative models of vitrinite reflectance evolution, the segmented profile can then in principle be used to estimate the magnitude of this event.

Graphic methods, based on the assumption that the logarithm of $R_{0}$ usually shows a linear depth trend and that the reflectance of immature vitrinite is approximately $0.2 \%$, are widely used to estimate erosion. Using the method of Dow (1977) on the vitrinite reflectance profile of the Pernille- 1 well results in an initial erosion estimate of about $1,500 \mathrm{~m}$. However, in this case the result of this method is subject to large uncertainties due to the limited depth range of the reflectance data.

In this study, vitrinite reflectance evolution is modelled as a function of subsidence and thermal history, and the aim is to give an estimate of the amount and timing of the Late Palaeozoic uplift/erosion by testing possible subsidence and thermal histories against vitrinite reflectance data from the Pernille-1 well of the Rønne Graben (Fig. 1). 


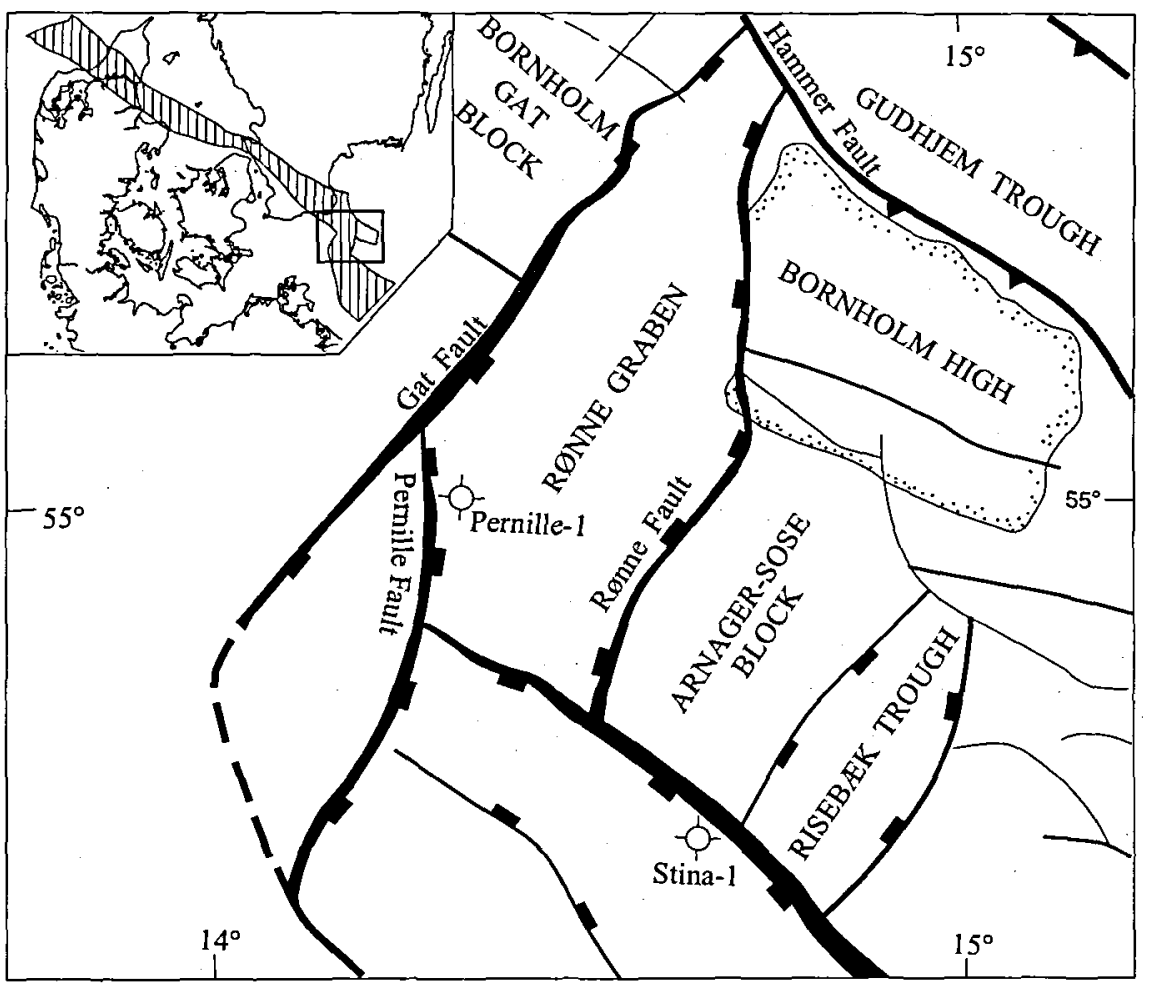

Fig. 1. General framework of the Tornquist Zone (upper left corner) and structural outline of the Rønne Graben and the adjacent area, including location of the Pernille-1 and Stina-1 wells. (Modified from Michelsen \& Nielsen (1993) and Hamann (1994)).

\section{Methods and data}

The use of discontinuous vitrinite reflectance profiles to estimate the amount and timing of erosion calls for a reconstruction of the subsidence history, the thermal history, and the vitrinite reflectance evolution.

Reconstruction of the subsidence history of the Pernille-1 well requires lithostratigraphic subdivision of the sedimentary column into periods of sedimentation, non-deposition, and erosion. This subdivision (Fig. 2) is based on the interpretation of well logs and the biostratigraphy of the Robertson Group (1989). The total thickness of Silurian and Ordovician sediments is estimated from the depth to seismic basement. The thickness of Cambrian sediments is estimated to equal that of the sequence onshore Bornholm and is included in the "basement" (Table 1).

The modelling method applied in this study assumes exponential depth-dependent compaction (Steckler \& Watts 1978), i.e. a porosity-depth relationship of the form:

$$
\varnothing(\mathrm{z})=\left(\varnothing_{0}-\varnothing_{\infty}\right) \exp (-\mathrm{z} / \mathrm{L})+\varnothing_{\infty}
$$

where $\mathrm{z}$ is the depth, and $\varnothing_{\infty}$ is the porosity at infinite depth. The compaction parameters of surface porosity $\varnothing_{0}$ and porosity decay length $\mathrm{L}$ of the individual lithologies (Table 1) are estimated from the present-day porosity profiles derived from bulk density logs. Poro-

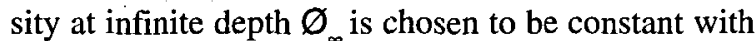
a value of 0.03 for sediments and 0.00 for basement and crystaline crust. Assuming that the present-day stratigraphic thickness is a consequence of cumulative compaction through time, the evolution of the sedimentary column is found by successive decompaction/ compaction of each layer (Steckler \& Watts 1978).

The thermal history of the sedimentary column is calculated by solving the one-dimensional transient heat equation for the compaction-corrected sedimentation history. The heat equation reads (Carslaw \& Jaeger 1959):

$\frac{\partial}{\partial z}\left(\lambda \frac{\partial T}{\partial z}\right)-\rho c \frac{\partial T}{\partial t}=-A$

$\mathrm{t}(\mathrm{z}=0, \mathrm{t})=\mathrm{T}_{\mathrm{s}}(\mathrm{t}) ;$

$\lambda \frac{\partial T}{\partial z}(z=D, t)=Q_{b}(t)$

where $\mathrm{z}$ is the depth below the sediment surface, $\lambda$ is the thermal conductivity, $T$ is the temperature, $\zeta \mathrm{c}$ is the heat capacity per unit volume, $t$ is time, $A$ is the radiogenic heat production, $T_{s}$ is the surface temperature, and $Q_{b}$ is the background heat flow at depth $D$. The transient heat equation is solved by a finite element method (Nielsen 1993).

The matrix thermal parameters (Table 1) are estima- 
ted from mean values of different lithologies (Uldall \& Balling 1989; Brigaud et al. 1990). Bulk thermal conductivity and heat production are calculated by applying the appropriate mixing laws, e.g. the geometrical mean law for thermal conductivity of mixtures. Throughout the modelling, constant values for matrix specific heat capacity of $850 \mathrm{Jkg}^{-1} \mathrm{~K}^{-1}$ for sediments and $900 \mathrm{Jkg}^{-1} \mathrm{~K}^{-1}$ for crustal material are applied.

The surface temperature through time is chosen to reflect the fact that the Baltic Shield and adjacent areas were previously closer to equator than today (Torsvik et al. 1992). A linear decrease from $15^{\circ} \mathrm{C}$ at $450 \mathrm{Ma}$ over $10^{\circ} \mathrm{C}$ at $100 \mathrm{Ma}$ to $0^{\circ} \mathrm{C}$ as present-day value was applied.

Background heat flow is one of the major unknown parameters, and available data does not allow for an unambiguous determination. In the method used in this study, the shape through time of the heat flow history curve is chosen a priori. Reconstruction of the thermal history is then performed by shifting the entire heat flow history by a constant value in order that the observed borehole temperatures are satisfied. The latter are corrected for drilling-induced temperature disturbances by the cylindrical source method of Nielsen et al. (1990).

Although vitrinite reflectance is one of the most widely used maturity indicators, the exact behavior of the macerals with increasing temperature and depth is not fully understood. Considerations as to the origin and quality of measured data (e.g. Tissot et al. 1987; Katz et al. 1988) and the properties of the chosen vitrinite reflectance model are therefore of importance. The measured reflectance data used in this study are average values from the Robertson Group (1989) and show an offset of approximately $0.8 \%$ at $3,150 \mathrm{~m}$. However, true vitrinite is probably absent from the Silurian strata of the Pernille-1 well, and Robertson Group (1989) suggests that the vitrinite-like macerals observed is partly chitinozoan.

Several authors have suggested that vitrinite-like macerals, with precursors such as graptolites, chitinozoans and scolecodonts, can be used as maturation indices (e.g. Goodarzi et al. 1988; Bertrand et al. 1987; Buchardt \& Lewan 1990). Bertrand et al. (1987) suggested that chitinozoan reflectivity is higher than that of vitrinite. Buchardt \& Lewan (1990) showed that at high temperatures reflectance of vitrinite-like macerals of the Cambrian-Ordovician Alum Shale in southern Scandinavia responded to heating in a way similar to vitrinite with slightly lower $R_{0}$ values for reflectances above $1 \%$. For the Silurian data of the Pernille-1 well the Robertson Group (1989) indicates a vitrinite reflectance equivalent of at least $1.3 \%-1.5 \%$ based on spore and kerogen colour.

Considering the uncertainties regarding the exact behavior and origin of the macerals, the modelling was performed assuming $a \mathrm{R}_{0}$ value of $1.7 \%$ at the erosional surface, and with quantification of the possible error introduced by this assumption.

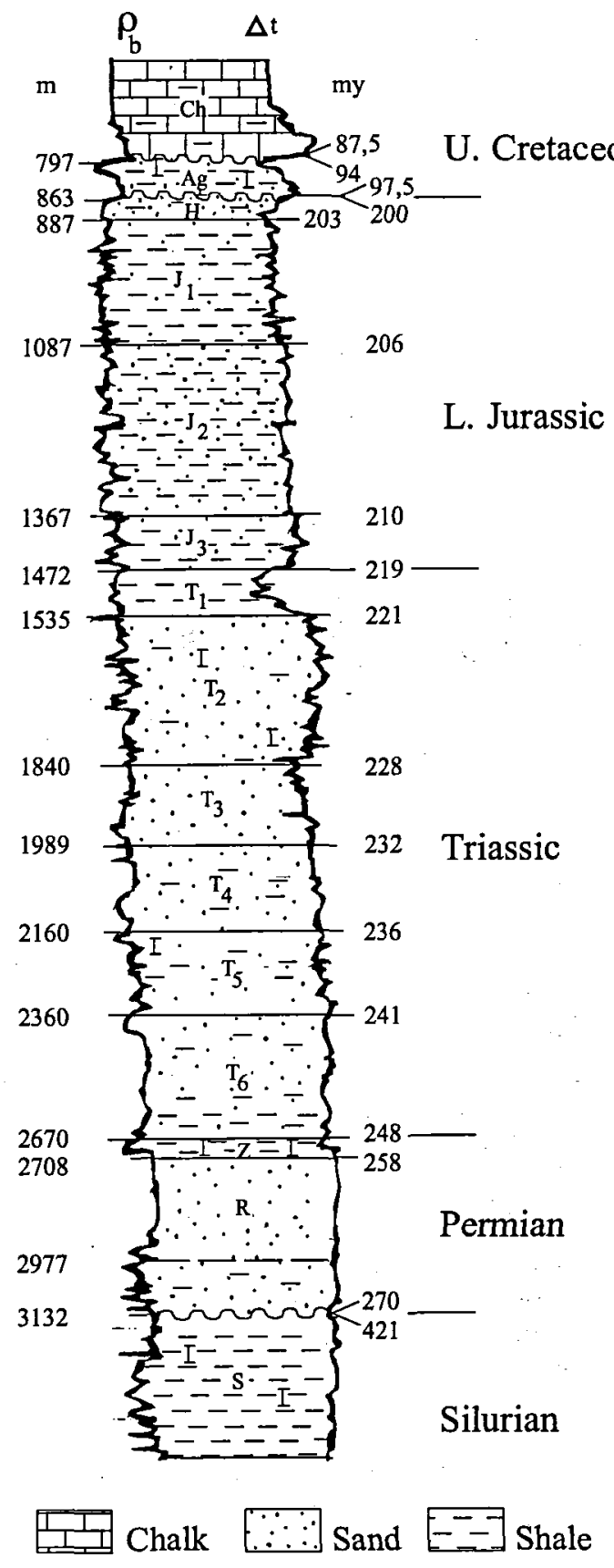

Fig. 2. Lithostratigraphic subdivision of the Pernille-1 well. Ch: undifferentiated chalk; Ag: Amager Greensand Equivalent; H: Hasle Fm. Equivalent; $\mathrm{J}_{1}-\mathrm{J}_{3}$ : Jurassic Group (Rønne Fm. Equivalent); $T_{1}-T_{6}$ : Triassic Group; Z: Zechstein; R: Rotliegendes; S: Silurian. $\rho_{b}$ is the bulk density $\log$ trace and $\Delta \mathrm{t}$ is the sonic log. Vertical scale is in two way time. (Modified from Robertson Group (1989)). 
Table 1. Physical and thermal input parameters. $\rho_{m}$ is the matrix bulk density. $\lambda_{m}$ is the matrix thermal conductivity. $A_{m}$ is the matrix radiogenic heat production. $\varnothing_{0}$ is the surface porosity, and $L$ is the porosity decay constant.

\begin{tabular}{lcccccc}
\hline Unit & $\begin{array}{l}\text { Thickness } \\
(\mathrm{km})\end{array}$ & $\begin{array}{l}\rho_{\mathrm{m}} \\
\left(\mathrm{kg} / \mathrm{m}^{3}\right)\end{array}$ & $\begin{array}{l}\lambda_{\mathrm{m}} \\
(\mathrm{W} / \mathrm{mC})\end{array}$ & $\begin{array}{l}\mathrm{A}_{\mathrm{m}} \\
\left(\mu \mathrm{W} / \mathrm{m}^{3}\right)\end{array}$ & $\begin{array}{l}\sigma_{0} \\
(\mathrm{~km})\end{array}$ \\
\hline Chalk & 0.797 & 2710 & 3.1 & 0.5 & 0.50 & 1.5 \\
Arnager Gr. & 0.066 & 2600 & 3.5 & 1.0 & 0.55 & 1.5 \\
Hasle Fm. & 0.024 & 2650 & 3.0 & 1.0 & 0.65 & 1.0 \\
Jurassic 1 & 0.200 & 2650 & 3.0 & 1.0 & 0.41 & 2.0 \\
Jurassic 2 & 0.280 & 2700 & 3.0 & 0.5 & 0.45 & 2.5 \\
Jurassic 3 & 0.105 & 2700 & 3.0 & 1.0 & 0.57 & 2.0 \\
Triassic 1 & 0.063 & 2680 & 3.1 & 1.0 & 0.64 & 1.0 \\
Triassic 2 & 0.305 & 2680 & 2.8 & 0.7 & 0.44 & 2.0 \\
Triassic 3 & 0.149 & 2700 & 2.8 & 1.0 & 0.44 & 2.5 \\
Triassic 4 & 0.171 & 2650 & 3.0 & 1.0 & 0.51 & 1.5 \\
Triassic 5 & 0.200 & 2650 & 3.1 & 0.5 & 0.52 & 1.5 \\
Triassic 6 & 0.310 & 2680 & 3.1 & 1.0 & 0.53 & 1.5 \\
Zechstein & 0.038 & 2700 & 3.1 & 1.0 & 0.55 & 2.0 \\
Rotliegendes & 0.424 & 2680 & 3.0 & 1.0 & 0.55 & 1.5 \\
U. Silurian/Devonian & 3.300 & 2680 & 2.3 & 1.0 & 0.50 & 3.0 \\
Silurian & 1.000 & 2690 & 2.8 & 1.5 & 0.59 & 1.5 \\
Basement & 1.000 & 2700 & 3.0 & 1.0 & 0.00 & - \\
Average crust & 30.000 & 2750 & 3.0 & 0.5 & 0.00 & - \\
Subcrustal lithosph. & 50.000 & 3000 & 3.0 & 0.0 & 0.00 & - \\
\hline
\end{tabular}
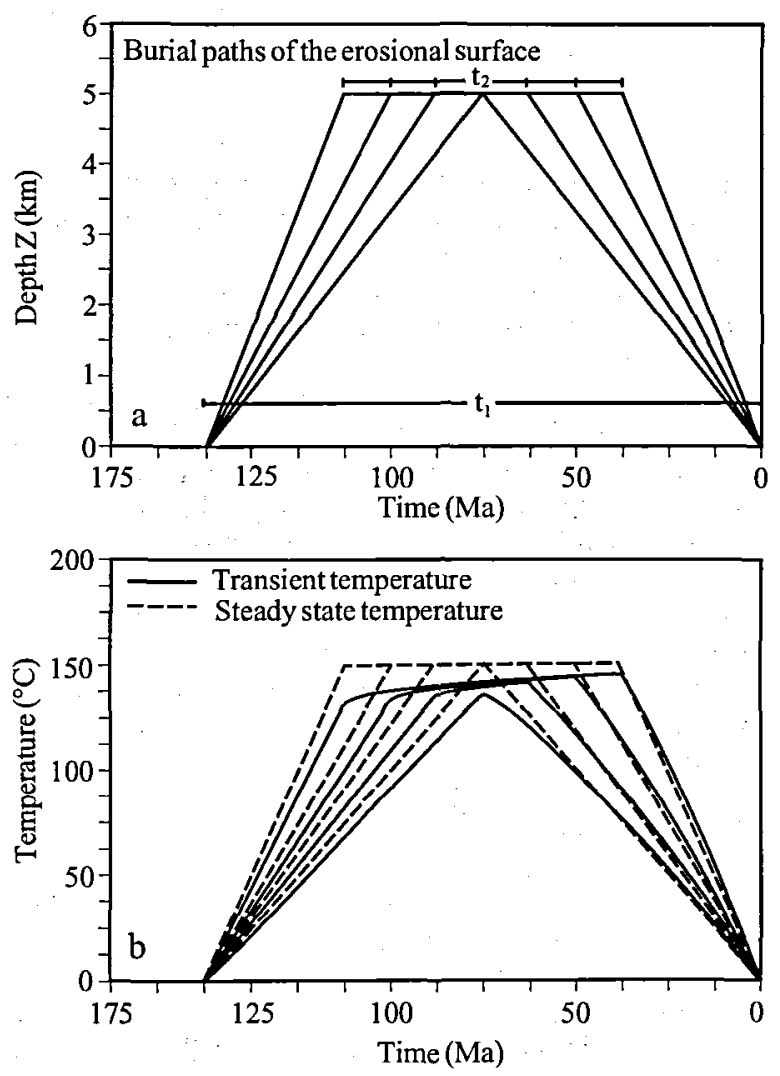

Fig. 3. a) Parameterization of the event causing the offset in vitrinite reflectance and $b$ ) corresponding transient and steady state temperature histories. $\mathrm{Z}$ is the depth of burial in $\mathrm{km}, \mathrm{t}_{1}$ is the total duration of the event causing the hiatus, and $t_{2}$ is the duration of deepest burial.
Based on the experiments of Throndsen et al. (1993) and Morrow \& Issler (1993), we choose to apply the vitrinite reflectance model of Sweeney \& Burnham (1990). This model is based on the theory that the composition of vitrinite versus time and temperature and therefore the reflectance - is controlled by the degassing of byproducts $\left(\mathrm{H}_{2} \mathrm{O}, \mathrm{CO}_{2}, \mathrm{CH}_{4}\right.$ and $\left.\mathrm{CH}_{n}\right)$. This temperature and time dependent evolution is described by 20 parallel and independently weighted first-order kinetic reactions with Arrhenius rate constants. The degassing of the $\mathrm{i}^{\text {th }}$ vitrinite component is described by:

$w_{i}(t)=w_{0 i} \exp \left(-\int_{0}^{t} k_{i}(\tau d \tau)\right)$

where $\mathrm{w}_{0 \mathrm{i}}$ is the normalized initial volatile content and $k_{i}=A \exp \left(-E_{i} / R T(t)\right)$ is the Arrhenius reaction rate. A is the frequency factor, $E_{i}$ is the $i^{\text {th }}$ activation energy, $R$ is the gas constant, and $T(t)$ is the absolute temperature. The transformation ratio $F$ of the vitrinite is given by:

$\mathrm{F}=1-\sum_{\mathrm{i}=1}^{20} \mathrm{w}_{\mathrm{i}}$.

The vitrinite reflectance is then calculated according to:

$\mathrm{R}_{0}=\exp (-1.6+3.7 \mathrm{~F}) \%$;

\section{Ambiguities and parameter}

\section{interdependencies in erosion estimation}

Estimation of the amount of erosion by the method of basin modelling combined with indicators of thermal 
maturation presents several difficulties related to the inherent ambiguities of the applied system. It is important to consider the extent to which the basic modelling parameters, i.e. heat flow, thermal conductivity, and amount and timing of the uplift and erosion, are constrained by the present-day data and how the effect of a change in one parameter can be neutralized or amplified by changes in other parameters.

Since $\mathrm{R}_{0}$ responds to temperature and time, there is a trade-off in the resulting erosion estimate between temperature and duration of deepest burial, such that a short duration of burial can be compensated by higher temperatures, and vice versa. Furthermore, the temperature during deepest burial is mainly produced by the harmonic mean thermal conductivity, the background heat flow, and the depth of burial.

In the case of the Pernille-1 well, the post-erosional evolution affects only the upper part of the vitrinite reflectance profile, because the temperature never again approaches the temperature attained during the period of deepest burial (Fig. 7a). This means that the fundamental ambiguity of the method can be quantified by considering the values of a few key variables during the period of burial and subsequent erosion. For the lower part of the vitrinite reflectance profile, i.e. the pre-erosion period, these variables are the equilibrium geothermal gradient, the duration of the burial and erosional event, the duration of deepest burial, and the depth of deepest burial.

Figs. 3-4 summarize the fundamental ambiguities and inter-dependencies of the system for a $R_{0}$ value of $1.7 \%$ at the erosional surface, as in the Pernille- 1 case.

Fig. 3a is a simple parameterization of the event causing the offset in the vitrinite reflectance profile. $t_{1}$ is the total time from the initiation of deposition to the end of the erosion. $t_{2}$ denotes the duration of a nondepositional period during deepest burial, and $\mathrm{Z}$ is the depth of the erosional surface as a function of time.

The $R_{0}$ value at the erosional surface is determined by its temperature history. Fig. $3 \mathrm{~b}$ shows the transient temperature history of the erosional surface for a total duration of the event $\left(t_{1}\right)$ of $150 \mathrm{Ma}$ and for various values of $t_{2}$. The thermal diffusivity of the homogeneous medium is $1^{*} 10^{-6} \mathrm{~m}^{2} / \mathrm{s}$. Also shown are the steady state temperature histories which would result if the transient thermal effects of deposition and erosion were not considered. The equilibrium geothermal gradient $\mathrm{Q} / \mathrm{C}$ is $30^{\circ} \mathrm{C} / \mathrm{km}$, resulting in an equilibrium temperature of $150^{\circ} \mathrm{C}$ during the time of deepest burial.

From Fig. $3 b$ it is apparent that the transient temperatures are cooler than the equilibrium temperatures during the period of burial, that they never reach the equilibrium temperatures during the period of deepest burial, and that they exceed the equilibrium temperatures during the period of erosion. The last is of no consequence for vitrinite reflectance evolution, as cooling immediately halts the irreversible process of maturation. However, it is apparent that incorrect consideration of transient thermal effects due to sedimen-

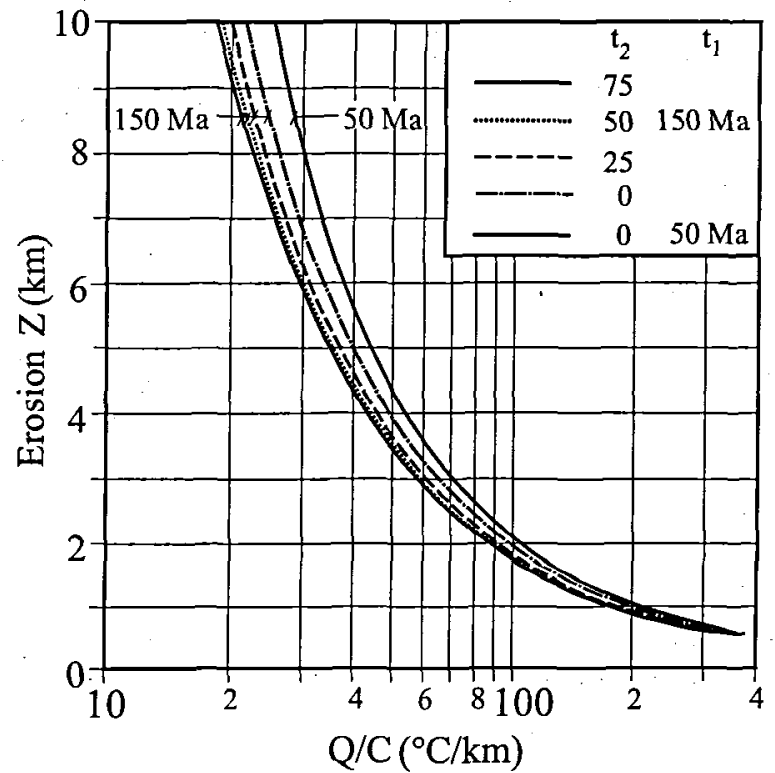

Fig. 4.Inter-dependency of the erosion estimate $\mathrm{Z}$, the equilibrium geothermal gradient $\mathrm{Q} / \mathrm{C}$, the total duration of the event causing the hiatus $t_{1}$, and the duration of deepest burial $t_{2} . Q$ is the heat flow and $C$ is the harmonic mean thermal conductivity of the medium.

tation and erosion can increase temperatures, and thereby $R_{0}$ values, resulting in an underestimation of the amount of erosion.

The value of $R_{0}$ produced during the events in Fig. 3 a depends mainly on the maximum temperature achieved. Since the corresponding temperature histories of Fig. $3 \mathrm{~b}$ achieve different maximum temperatures, the resulting $R_{0}$ value of each event is also different. The fundamental ambiguity of erosion estimation now arises from the fact that for each of the burial histories of Fig. 3a it is possible to find another value of the temperaure gradient $\mathrm{Q} / \mathrm{C}$ so that the resulting temperature histories of Fig. $3 \mathrm{~b}$ are modified to produce the same $R_{0}$ value at the erosional surface. Alternatively, for the same value of $\mathrm{Q} / \mathrm{C}$ it is possible to find different values of the maximum depth of burial so that the resulting temperature histories produce the same $R_{0}$ value at the erosional surface.

Fig. 4 quantifies the inter-dependency of the basic parameters which results in a $R_{0}$ value of $1.7 \%$ at the erosional surface, as in the Pernille-1 case. The effect of changing the total duration of the event is shown with values of $t_{1}$ of $50 \mathrm{Ma}$ and $150 \mathrm{Ma}$. For $t_{1}=150$ Ma the effect of changing the duration of the period of deepest burial is shown with values of $0,25,50$, and $75 \mathrm{Ma}$.

The general hyperbolic relationship between the amount of erosion and the equilibrium geothermal gradient is due to the fact that a given $R_{0}$ value at the erosional surface during burial at depth $\mathrm{Z}$ mainly is a 


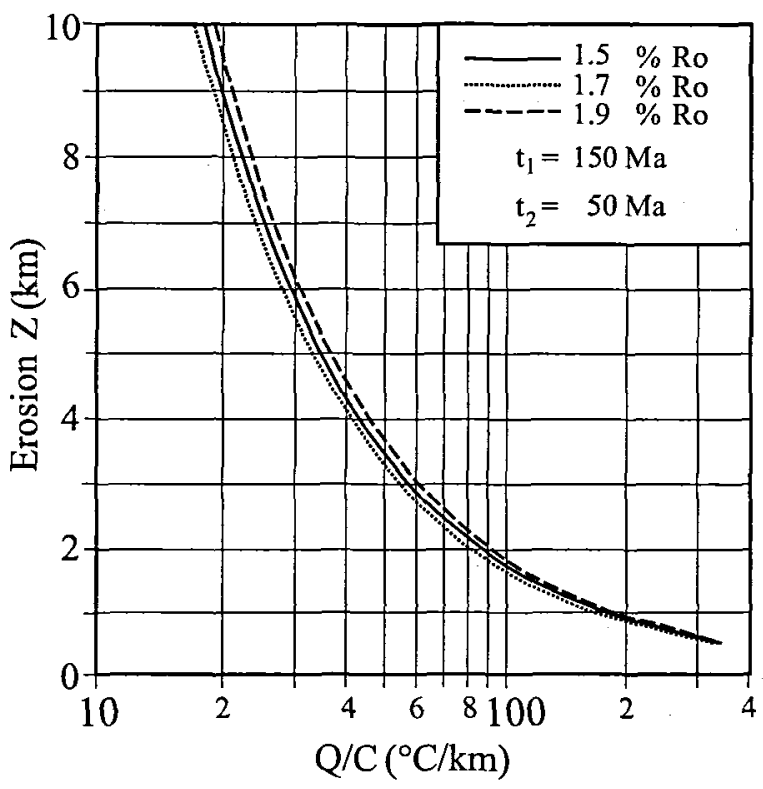

Fig. 5. Erosion estimate $\mathrm{Z}$ as a function of the equilibrium geothermal gradient $\mathrm{Q} / \mathrm{C}$ for various vitrinite reflectance values at the erosional surface. $Q$ is the heat flow and $C$ is the harmonic mean thermal conductivity of the medium.

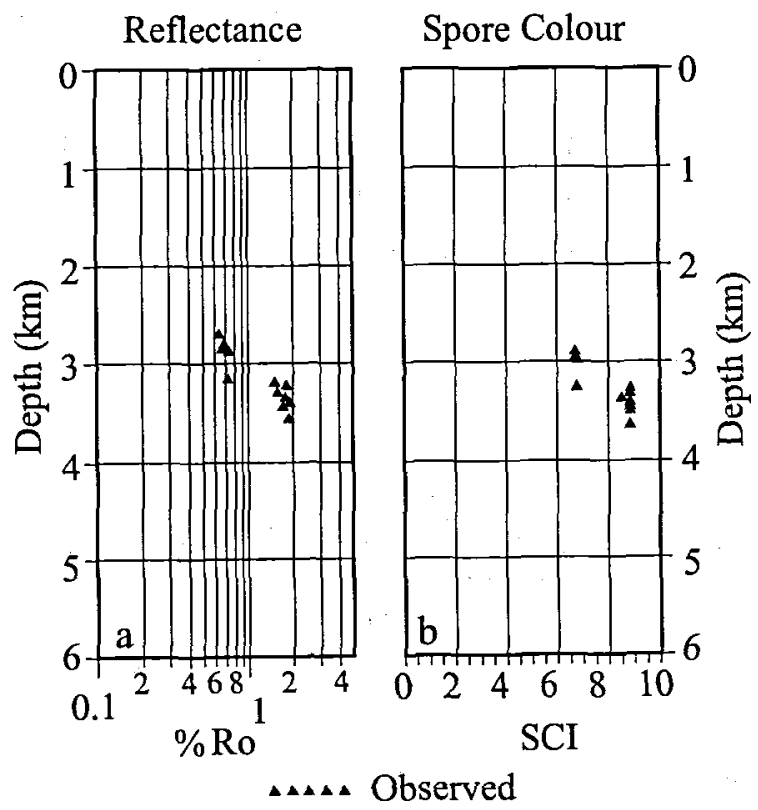

Fig. 6. Distribution of a) vitrinite reflectance $\left(\% R_{0}\right)$ and $\left.b\right)$ spore colour (SCI) data with depth from the Pernille-1 well (Robertson Group 1989). question of achieving a certain maximum temperature $\mathrm{TR}_{0}$ characteristic of that $\mathrm{R}_{0}$ value. Since the temperature $\mathrm{T}$ at depth $\mathrm{Z}$ is mainly given by $\mathrm{T}=\mathrm{ZQ} / \mathrm{C}$ (Fourier's law), the hyperbolic relationship $\mathrm{Z}=\mathrm{T}_{\mathrm{R}_{0}} /(\mathrm{Q} / \mathrm{C})$ follows.

It is apparent from Fig. 4 that values of $Q$ and $C$ which keep the geothermal gradient $\mathrm{Q} / \mathrm{C}$ constant result in the same erosion estimate.

Increasing values of the total duration of the event $t_{1}$, and the duration of deepest burial $t_{2}$ results in decreasing erosional estimates, because the time available for temperature equilibration during deepest burial increases. The offset between the curves produced by changing the duration of deepest burial $t$ is due to the transient effects of sedimentation and erosion, and to a lesser extent to the delay in vitrinite reflectance evolution during heating. Finally, Fig. 4 shows that the erosion estimate is more sensitive to temperature than time.

The importance of considerations as to the origin and quality of the measured data and the properties of the chosen vitrinite reflectance model is quantified in Fig. 5. The erosion estimate $Z$ as a function of the geothermal gradient $Q / C$ is shown for $R_{0}$ values at the erosional surface of $1.9,1.7$, and $1.5 \%$, representing a difference of $\pm 0.2 \%$ in the data of the Pernille- 1 case. This difference could represent the difference in reflectance between the vitrinite-like macerals of the Pernille-1 well and true vitrinite. The difference could also be caused by the measurement process, e.g. inadequate identification of the macerals or quality of the polish (e.g. Tissot et al. 1987), or could represent the effect of choosing a kinetically based vitrinite reflectance model as compared with other models, e.g. the more time sensitive TTI-based models (e.g. Issler 1984; Waples 1980).

Fig. 5 shows that an over- or underestimation of the $R_{0}$ value by $\pm 0.2 \%$ at the erosional surface introduces an error in the erosion estimate of up to 500 metres, depending on the thermal regime of the system. For the more typical thermal regime, i.e. geothermal gradients greater than $30^{\circ} \mathrm{C} / \mathrm{km}$, the possible error amounts to $200-300 \mathrm{~m}$.

\section{Results and discussion}

The Late Palaeozoic uplift and erosion in the Rønne Graben west of Bornholm is evident as discontinuous trends in both vitrinite reflectance and spore colour profiles (Figs 6a-6b). Spore colour data, however, are semiqualitative as compared with vitrinite reflectance and are therefore not used in the quantitative modelling of this study.

The modelling was performed by choosing the best possible parameters for the known part of the sedimentation history and letting the parameters during the Palaeozoic burial and uplift and erosion be the major unknowns. 


\section{Well Pernille -1}
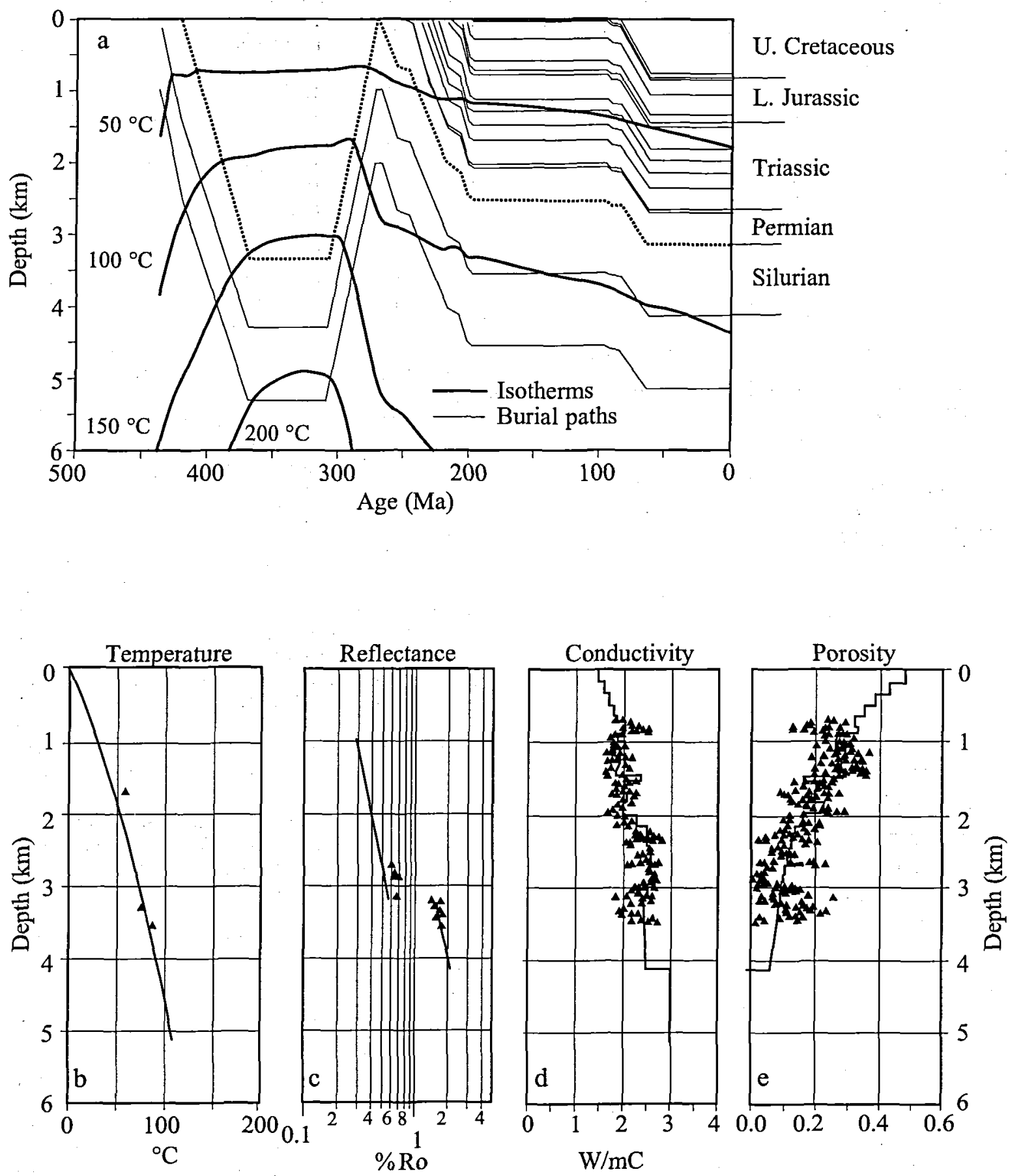

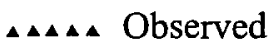

\section{Modelled}

Fig. 7. Composite figure of a) a sedimentation diagram showing burial paths of each layer and temperature evolution as isotherms. The dotted line represents the erosional surface. b) temperature, c) vitrinite reflectance, d) thermal conductivity, and e) porosity versus depth are shown for observed (triangles) and modelled (solid line) values. Porosity is calculated as mean values of $10 \mathrm{~m}$ intervals causing the scattering of data. 
Table 2. Sensitivity of the erosion estimate to the geothermal gradient.

\begin{tabular}{llll}
\hline Q/C & $\begin{array}{l}\text { Erosion } \\
\text { estimate } \\
(\mathrm{m})\end{array}$ & $\begin{array}{l}-10 \% \text { in } \\
\mathrm{Q} / \mathrm{C} \\
(\mathrm{m})\end{array}$ & $\begin{array}{c}+10 \% \text { in } \\
\mathrm{Q} / \mathrm{C} \\
(\mathrm{m})\end{array}$ \\
\hline 100 & 1,700 & 1,800 & 1,650 \\
70 & 2,400 & 2,700 & 2,200 \\
50 & 3,300 & 3,700 & 3,000 \\
40 & 4,200 & 4,900 & 3,700 \\
30 & 5,800 & 7,300 & 5,000 \\
\hline
\end{tabular}

For the parameters chosen from the modelling procedure described above, $3,300 \mathrm{~m}$ of uplifted and eroded Upper Silurian and Devonian sediments provide the modelled curve with the best fit to the vitrinite reflectance profile of the Pernille-1 well. Fig. 7 is a graphic representation of the modelling results.

Fig. 7a shows the sedimentation diagram of the Pernille-1 well, including the temperature evolution presented as isotherms. The dotted line is the burial path of the erosional surface represented by the segmented vitrinite reflectance profile in this study. As can be seen, this erosional surface, i.e. the Silurian sediments, has experienced temperatures above $150^{\circ} \mathrm{C}$ during the period of deepest burial (370-310 Ma) as a result of rapid sedimentation of Devonian sediments with low thermal conductivity.

The agreement between the modelled present-day temperature profile and observed borehole temperatures in Fig. $7 \mathbf{b}$ is because the temperatures have been used to adjust the general level of the background heat flow.

Vitrinite reflectance versus depth (Fig. 7c) shows consistency with data in the pre-erosion part. The offset between modelled and measured $R_{0}$ above the unconformity could be an effect of the Late Cretaceous/ Early Tertiary inversion and subsequent erosion, but has not been modelled, as this part of the temperature history is of little consequence for the evolution of the pre-erosion part of the vitrinite reflectance profile.

The thermal conductivity profile of Fig. 7d shows an over-all agreement between modelled values and those derived from well logs. Discrepancies in certain levels are seen to correspond with similar discrepancies in the porosity curve, as the porosity data were used for calculating the conductivity values.

Fig. 7e shows observed and modelled porosity versus depth. Discrepancies in certain levels are possibly caused by caving or fractures affecting the density log and thereby the derived porosity data. In these levels, average porosity values for the individual lithologies were used as input parameters in the modelling. Although the porosity profile data will reflect the deepest burial of the sedimentary column, the Late Palaeozoic erosion is not expected to be seen as the present-day depth nearly equals the depth of deepest burial.

The inter-dependency of the key modelling para- meters illustrated in Fig. 4 means that the erosion estimate based on the vitrinite reflectance evolution can be changed in any one of three ways: 1) by changing the background heat flow, 2) by changing the thermal conductivity of the overburden, and 3 ) by changing the total duration of the event or the period of deepest burial.

1) Evidence of widespread Carboniferous/Permian volcanism in the Danish and Baltic areas (e.g. Pegrum 1984) suggests that the thermal regime of the lithosphere during this period was substantially warmer than at the present-day. Consequently, the shape of the background heat flow history curve was chosen to reflect this by increasing the Palaeozoic heat flow density by $25 \mathrm{~mW} / \mathrm{m}^{2}$ above the present-day value. The sensitivity of the erosion estimate to the choice of heat flow is quantified in Fig. 4. For example, our favoured erosion estimate of $3,300 \mathrm{~m}$ corresponds to a geothermal gradient of $50^{\circ} \mathrm{C} / \mathrm{km}$. A $10 \%$ change in Q induces a $10 \%$ change in the gradient $\mathrm{Q} / \mathrm{C}$, corresponding to gradients of $45^{\circ} \mathrm{C} / \mathrm{km}(-10 \%)$ and $55^{\circ} \mathrm{C} / \mathrm{km}(+10 \%)$. The associated erosion estimates are $3,700 \mathrm{~m}$ and 3,000 m (Table 2).

2) Devonian sediments are not found in the Danish area. However, the proximity of the Rønne Graben to the Fennoscandian Shield, and the generally high gamma-log readings and angular texture of the grains throughout the sedimentary column in the Pernille-1 well, indicates relatively immature sediments, i.e. a high content of feldspars with low thermal conductivity (Brigaud et al. 1990). An overburden with low conductivity and high sedimentation rate acts as an insulating layer, resulting in a rapidly increasing temperature of the underlying sedimentary column. This so-called blanketing effect (Nielsen \& Balling 1990 ) is seen in Fig. 7a as an upward bend of the isotherms between 300 and $400 \mathrm{Ma}$. A matrix thermal conductivity of $2.3 \mathrm{~W} / \mathrm{mC}$ for the missing sediments was chosen. The sensitivity of the erosion estimate to the thermal conductivity $\mathrm{C}$ of the eroded sediments is quantified in Fig. 4. A $10 \%$ change in $\mathrm{C}$ results in gradients of $45^{\circ} \mathrm{C} / \mathrm{km}(+10 \%)$ and $55^{\circ} \mathrm{C} / \mathrm{km}(-10 \%)$. The associated erosion estimates are $3,700 \mathrm{~m}$ and 3,000 m (Table 2).

3) The limits of seismic resolution and the uncertainty of the biostratigraphic data in the interval between 2,977 and 3,132 m mean that a number of scenarios are possible for the timing of the period of deposition, uplift, and erosion. The best result during modelling was achieved with Upper Silurian and Devonian sedimentation (421-370 Ma), a period of non-deposition (370-310 Ma), and Late Carboniferous/ Early Permian uplift and erosion (310-270 Ma).

The modelled result of 3,300 metres of erosion shown in Fig. 7 must be tempered with the number of assumptions made and the limitations of the various models and data aquisition methods used, e.g. the possible introduction of errors by calculating the porosity from density $\log$ data and subsequently using this porosity 
for calculation of thermal parameters, in both cases using estimated matrix values. i

The one-dimensional modelling methods applied in this study mean that it is important to consider the validity of the modelling result in the rest of the Rønne Graben area. Lateral heat flow, for example, is not considered. The close setting of the Pernille-1 well to the Pernille Fault (Figs 1\&8) could result in abnormal parameters of the sediments, caused by compressional stress during the Late Cretaceous/Early Tertiary inversion. These parameters could in turn affect the modelling result as well as cause a difference in lateral heat flow. Furthermore, the very complex structural framework of the Rønne Graben and adjacent areas means that the magnitude of uplift presented in this study might be local e.g. due to block rotations (Hamann 1994). Such deviation from the one-dimensionality is indicated by the porosity data from the Stina- 1 well south-east of the Rønne Graben (Fig. 1), which shows a much deeper burial history.

There are no surface heat flow data from the Bornholm area available for calibration. However, interpolating values from the Danish (Balling 1992) and adjacent areas to the area around Bornholm indicates values of approximately $50-55 \mathrm{~mW} / \mathrm{m}^{2}$. This heat flow value, and values between $50-70 \mathrm{~mW} / \mathrm{m}^{2}$ observed in north eastern Germany, northern Poland, and southern Sweden (Hurtig et al. 1992), are consistent with the modelled present-day surface heat-flow density of 49 $\mathrm{mW} / \mathrm{m}^{2}$ obtained in this study. It is possible that thermal refraction effects, which must occur in narrow pullapart basins (Pitman \& Andrews 1985) if lateral conductivity contrasts exist, are responsible for the low value of the present-day heat flow. The modelled surface heat flow during the event causing the offset in vitrinite reflectance is $74 \mathrm{~mW} / \mathrm{m}^{2}$. Thus the very high geothermal gradient of approximately $50^{\circ} \mathrm{C} / \mathrm{km}$ (maximum temperatures of $160-165^{\circ} \mathrm{C}$ ) obtained during deepest burial is primarily due to the low conductive overburden rather than a high palaeoheat-flow density.

The Late Palaeozoic evolution proposed in this study, i.e. only Upper Silurian and Devonian sedimentation and a single erosional phase, might be simplified. Occurrence of reworked Lower-Middle Carboniferous spores and pollen in Jurassic sediments onshore Bornholm indicates Carboniferous sedimentation in the Bornholm area (Nielsen \& Koppelhus 1991). Furthermore, several erosional phases has been documented south of the Caledonian Deformation Front (Piske \& Neumann 1993). However, the limited sensitivity of the vitrinite reflectance evolution to the duration of the burial event, as shown in Fig. 4, precludes an exact modelling of the sedimentation history.

The erosion estimate of $3,300 \mathrm{~m}$ is in agreement with other studies from the Rønne Graben. Hamann (1994) estimated a total Late Palaeozoic erosion of 1,000-5,000 metres in the Rønne Graben with approximately 4,000 metres close to the Pernille Fault from reconstructed
Line NH-87B-101

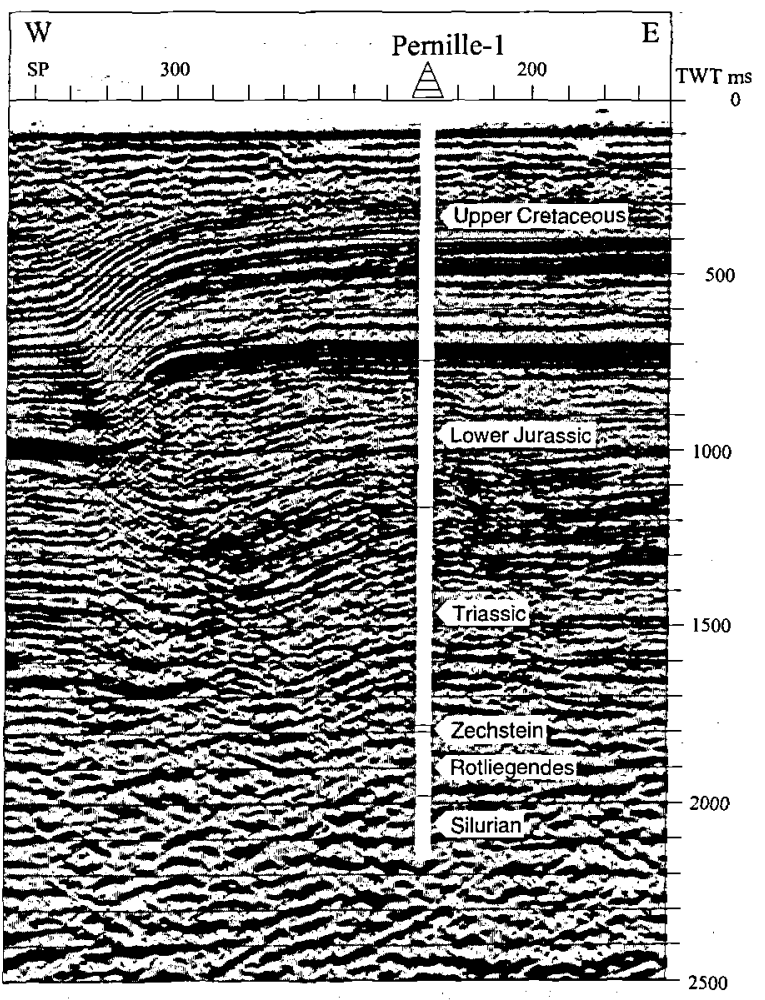

Fig. 8. Location of the Pernille-1 well on seismic line NH$87 \mathrm{~B}-101$. Note the disturbance of the seismic reflectors between SP 200-320.

original thicknesses of Palaeozoic sediments. Vejbæk et al. (1994) used modelling of maturation history to estimate 2,700 metres of Late Carboniferous uplift and erosion. Buchardt \& Nielsen (1985) estimated a minimum temperature at deepest burial of $90^{\circ} \mathrm{C}$, corresponding to a minimum depth of 2,000 metres, for Silurian sediments onshore Bornholm, using the composition of carbon and oxygen isotopes.

\section{Conclusion}

Using basin modelling to simulate sedimentation history and vitrinite maturation, this study has shown that Late Carboniferous/Early Permian uplift and erosion of approximately 3,300 metres of Upper Silurian and Devonian sediments is needed to reproduce the offset in the vitrinite reflectance profile of the Pernille-1 well. This amount of erosion is consistent with results from other studies in the Rønne Graben area.

By quantification of the inter-dependency of the key variables, it is evident that the geothermal gradient, expressed as $\mathrm{Q} / \mathrm{C}$, is the most sensitive model parameter. The maximum temperature of $160-165^{\circ} \mathrm{C}$ obtained 
in this case corresponds to a geothermal gradient of approximately $50^{\circ} \mathrm{C} / \mathrm{km}$. Using the fact that the sensitivity of the erosion estimate to the geothermal gradient depends on the value of $\mathrm{Q} / \mathrm{C}$, we find that a $\pm 10 \%$ error in the geothermal gradient of this study yields erosion estimates between 3,000 and $3,700 \mathrm{~m}$.

This study has also presented an example of basin modelling as a tool for providing useful complementary information for use with more traditional methods in assessing the structural history of sedimentary basins.

\section{Dansk sammendrag}

Med udgangspunkt $i$ et diskontinuert vitrinit reflektans profil fra Pernille-1 boringen i Rønne Graven, Bornholm, er bassinmodellering anvendt til at estimere størrelsen af den sen palæozoiske hævning og erosion. Modellering af boringens indsynknings-, temperaturog vitrinit modningshistorie viser, at inkonformiteten repræsenterer $3.300 \mathrm{~m}$ Sen Karbon hævning og erosion af $\phi v r e$ silure og devone sedimenter. Maximum temperaturer under dybeste begravelse er $160-165^{\circ} \mathrm{C}$, svarende til en geotermal gradient på $50^{\circ} \mathrm{C} / \mathrm{km}$.

Følsomhedsanalyse af de vigtigste modelparametre anvendes til evaluering af nøjagtigheden af det modellerede resultat. Den geotermale gradient er den mest følsomme parameter og en $\pm 10 \%$ usikkerhed på denne tilsvarer erosionsestimater på henholdsvis $3.000 \mathrm{og}$ $3.700 \mathrm{~m}$.

\section{Acknowledgements}

We would like to thank Niels Balling, John Korstgård, Mads Huuse (Department of Earth Science, Aarhus University), and the referees Ole V. Vejbæk and Svend Stouge for constructive reviews of the manuscript and stimulating discussions. Also, the patient help of Grethe Nielsen with the illustrations is gratefully acknowledged.

\section{References}

Balling, N. 1992: Denmark. In Hurtig, E., Cermák, V., Haenel, R. \& Zui, V. (eds) Geothermal Atlas of Europe. Hermann Haack Verlagsgesellschaft mbH, Gotha. 25-28.

Bertrand, R. \& Héroux, Y. 1987: Chitinozoan, graptolite, and scolecodont reflectance as an alternative to vitrinite and pyrobitumen reflectance in Ordovician and Silurian strata, Anticosti Island, Quebec, Canada. The American Association of Petroleum Geologists Bulletin 71, 951957.
Brigaud, F., Chapman, D. S. \& Le Douaran, S. 1990: Estimating thermal conductivity in sedimentary basins using lithologic data and geophysical well logs. The American Association of Petroleum Geologists Bulletin 74, 14591477.

Buchardt, B. \& Lewan, M. D. 1990: Reflectance of vitrinitelike macerals as a thermal maturity index for CambrianOrdovician Alum Shale, southern Scandinavia. The American Association of Petroleum Geologists Bulletin 74, 394-406.

Buchardt, B. \& Nielsen, A. T. 1984: Carbon and oxygen isotope composition of Cambro-Silurian limestone and anthraconite from Bornholm: Evidence for deep burial diagenesis. Bulletin of the Geological Society of Denmark 33, 415-435.

Carslaw, H. S. \& Jaeger, J. C. 1959: Conduction of Heat in Solids. Oxford University Press. 510 pp.

Dow, W. G. 1977: Kerogen studies and geological interpretations. Journal of Geochemical Exploration 7, 79-99.

Goodarzi, F., Stasiuk, L. D. \& Lindholm, K. 1988: Graptolite reflectance and thermal maturity of Lower and Middle Ordovician shales from Scania, Sweden. Geologiska Föreningens i Stockholm Förhandlingar 110, 225-236.

Hamann, N. E. 1994: Den tektoniske udvikling af Rønne Graven - Et seismisk studie. Unpublished Ph.D. thesis. Copenhagen University. 136 pp.

Hurtig, E., Cermék, V., Haenel, R. \& Zui, V. 1992: Geothermal Atlas of Europe. Hermann Haack Verlagsgesellschaft $\mathrm{mbH}$, Gotha.

Issler, D. R. 1984: Calculation of organic maturation levels for offshore eastern Canada - implications for general application of Lopatin's method. Canadian Journal of Earth Sciences 21, 477-488.

Katz, B. J., Pheifer R. N. \& Schunck D. J. 1988: Interpretation of discontinuous vitrinite reflectance profiles. The American Association of Petroleum Geologists Bulletin 72, 926-931.

Liboriussen, J., Ashton, P. \& Tygesen, T. 1986: The tectonic evolution of the Fennoscandian Border Zone in Denmark. Tectonophysics 137, 21-29.

Michelsen, O. \& Nielsen, L. H. 1993: Structural development of the Fennoscandian Border Zone, offshore Denmark. Marine and Petroleum Geology 10, 124-134.

Middleton, M. F. 1982: Tectonic history from vitrinite reflectance. Geophysical Journal of the Royal Astronomical Society 68, 121-132.

Morrow, D. W. \& Issler, D. R. 1993: Calculation of vitrinite reflectance from thermal histories: A comparison of some methods. The American Association of Petroleum Geologists Bulletin 77, 610-624.

Nielsen, S. B. 1993: Fast Monte Carlo simulation of hydrocarbon generation. In Doré, A. G. et al. (eds) Basin Modelling: Advances and Applications, Norwegian Petroleum Society Special Publication 3, 265-276. Amsterdam: Elsevier.

Nielsen, S. B. \& Balling, N. 1990: Modelling subsidence, heat flow, and hydrocarbon generation in extensional basins. First Break 8, 23-31.

Nielsen, S. B., Balling, N. \& Christiansen, H. S. 1990: Formation temperatures determined from stochastic inversion of borehole observations. Geophysical Journal International 101, 581-590. 
Nielsen, L. H. \& Koppelhus, E. B. 1991: Reworked Carboniferous palynomorphs from Lower Jurassic Bornholm and their palaeogeographic significance. Bulletin of the Geological Society of Denmark 38, 253-266.

Pegrum, R. M. 1984: The extension of the Tornquist Zone in the Norwegian North Sea. Norsk Geologisk Tidsskrift $64,39-68$.

Piske, J. \& Neumann, E. 1993: Tektonische gliederung des prävariszischen untergrundes in der südwestlichen Ostsee. Geologisches Jahrbuch, Hannover, A131, 361-388.

Pitman, W. C. \& Andrews, J. A. 1985: Subsidence and thermal history of small pull-apart basins. In Biddle, K. T. \& Christie-Blick, N. (eds) Strike-Slip Deformation, Basin Formation and Sedimentation. Special Publication Society of Economic Paleontologists and Mineralogists 37, 4549.

Robertson Group public limited company. 1989: Pernille-1 Report No. 4021/Ia.

Steckler, M. S \& Watts, A. B. 1978: Subsidence of the Atlantic-type Continental margin off New York. Earth and Planetary Science Letters 41, 1-13.

Sweeney, J. J. \& Burnham, A. K. 1990: Evaluation of a simple model of vitrinite reflectance based on chemical kinetics. The American Association of Petroleum Geologists Bulletin 74, 1559-1570.

Throndsen, T., Andresen, B. \& Unander, Å. 1993: Comparison of different models for vitrinite reflectance evolution using laboratory calibration and modelling of well data. In Doré, A. G. et al. (eds) Basin Modelling: Advances and Applications, Norwegian Petroleum Society Special Publication 3, 127-133. Amsterdam: Elsevier.

Tissot, B. P., Pelet, R. \& Ungerer, P. 1987: Thermal history of sedimentary basins, maturation indices, and kinetics of oil and gas generation. The American Association of Petroleum Geologists Bulletin 71, 1445-1466.

Torsvik, T. H., Smethurst, M. A., Van der Voo, R., Trench, A., Abrahamsen, N. \& Halvorsen, E. 1992: Baltica. A synopsis of Vendian-Permian palaeomagnetic data and their palaeotectonic implications. Earth-Science Reviews $33,133-152$.

Uldall, A. \& Balling, N. 1989: Petrophysics of selected wells from the Danish Central Graben - porosity, thermal conductivity and density determinations. Rapport til Statoil. Laboratoriet for Geofysik, Aarhus Universitet. 95 pp.

Vejbæk, O. V. 1985: Seismic stratigraphy and tectonics of sedimentary basins around Bornholm Southern Baltic. Geological Survey of Denmark 8 Series A. 30 pp.

Vejbæk, O. V., Stouge, S. \& Poulsen, K. D. 1994: Palaeozoic tectonic and sedimentary evolution and hydrocarbon prospectivity in the Bornholm area. Geological Survey of Denmark 34 Series A. 23 pp.

Waples, D. 1980: Time and temperature in petroleum formation: Application of Lopatin's method to petroleum exploration. The American Association of Petroleum Geologists Bulletin 64, 916-926. 